\title{
METHODS AND TECHNOLOGIES OF TEACHING MEDICAL STUDENTS ON THE BASIS OF INTERDISCIPLINARY INTEGRATION
}

\author{
С. В. Бондаренко, О. І. Пилипишин, М. О. Сопіга \\ Тернопільський національний медичний університет імені І. Я. Горбачевського МОЗ Украӥни \\ МЕТОДИ ТА ТЕХНОЛОГІЇ НАВЧАННЯ СТУДЕНТІВ-МЕДИКІВ \\ НА ЗАСАДАХ МІЖДИСЦИПЛІНАРНОЇ ІНТЕГРАЦІї
}

\begin{abstract}
The article attempts to reflect the modern content of educational services in obtaining medical education in higher education institutions, which will reflect the nature of economic and social development of Ukraine and is designed to change primarily the paradigm of higher medical education. The definition of requirements for the future specialist, new standards based on the competence approach and sharing the philosophy of interdisciplinary integration are outlined.

Describes important teaching methods in modern higher medical education that shape the personality of the future specialist with a new outlook and thinking that will successfully compete with professionals in the field in the labor market, timely, promptly respond to various demands of society. Teaching technologies and modernization of higher medical education are identified, the purpose of which is to focus on new standards of higher education, which in turn should become the next generation of standards.

Interdisciplinary integration and application of interdisciplinary technologies in the training of future medical professionals will allow the formation of a new level of critical thinking that can comprehensively solve the problems of clinical practice and comprehensive integration.
\end{abstract}

Key words: medical education; competencies; innovation; technology.

Анотація. У статті зроблено спробу відображення сучасного змісту надання освітніх послуг при здобутті медичної освіти у ЗВО, який буде відображати характер економічного та соціального розвитку України і покликаний на зміну передовсім парадигми вищої медичної освіти. Окреслено визначення вимог до майбутнього фахівця, нові стандарти, що базуються на компетентнісному підході і поділяють філософію міждисциплінарної інтеграції.

Описано важливі методи навчання в сучасній вищій медичній освіті, які формують особистість майбутнього фахівця з новим кругозором та мисленням, що дозволить успішно конкурувати з фахівцями в галузі на ринку праці, своєчасно, оперативно реагувати на різноманітні запити суспільства. Визначено технології навчання та модернізацію вищої медичної освіти, метою яких є орієнтація на нові стандарти вищої освіти, що, у свою чергу, мають стати наступним поколінням стандартів.

Міждисциплінарна інтеграція та застосування міждисциплінарних технологій у підготовці майбутніх фахівців медичного профілю дозволять вийти на формування нового рівня критичного мислення, що здатне комплексно вирішувати завдання клінічної практики та всебічної інтеграції.

Ключові слова: медична освіта; компетентності; інновація; технологія.

Introduction. The system of higher medical education provides for the introduction of new educational technologies and methods of teaching medical students. Thus, it is becoming increasingly clear that modern higher medical education is moving away from the informative style of learning, focused on the transfer of knowledge, skills and moves to

(c) S. V. Bondarenko, O. I. Pylypyshyn, M. O. Sopiha the modern based on the formation of the ability to master the profession of the future doctor. There fore, the priority in the development of the modern system of higher medical education should be the coexistence of two learning strategies - traditional and innovative, the formation of student readiness for the development of various forms of clinical thinking and personal development. Today, employers want 
at least 10 professional skills that a future specialist must have:

- vision of the problem in the complex;

- self-criticism;

- creative thinking;

- human resources management;

- interact with people;

- intelligence;

- own point of view;

- customer focus;

- ability to negotiate;

- flexibility of mind.

Therefore, the personality of a medical student should become a priority of modern higher medical education, which is in constant professional and personal development. One of the tasks of the teacher is to teach the student to learn, work, coexist and live. In turn, dissatisfaction with the quality of education, both employers and educators themselves, and awareness of the need to reform the system of professional training of future doctors, necessitate the need to update the requirements for its competence.

The aim - of the article is to reveal modern teaching technologies in the training of future medical professionals on the basis of interdisciplinary integration.

Theoretical framework. In the categorical apparatus of modern higher medical education, the concept of innovation should be a new, high-quality education. According to I. Dychkivska, innovation is change, renewal; a new approach, the creation of a qualitatively new, the use of the known for other purposes [1].

Innovations in teaching technologies (updating teaching methods) are important for determining modern teaching methods in higher medical education. Learning technology models the way of mastering a specific educational material within the relevant subject, topic. In many ways, it is close to a separate technique. Learning technology covers the content, forms and methods of learning.

The definition of the term "method" comes from the Greek word "methodos" - activity, a way of advancing to the truth.

Teaching methods are an orderly activity of the teacher and students, which includes a system of components and is aimed at solving educational tasks in the classroom.

Verbal teaching methods include explanation, instruction, storytelling, conversation, educational discussion.

Verbal interpretation of concepts, phenomena, principles of operation of devices, visual aids, words, terms is an explanation. Used mainly when teaching new material, as well as in the process of consolidation, especially when the teacher feels that students do not understand something. Explanation is often accompanied by various means of visualization, observation, experiments. The success of the explanation depends on its provability, logic, clarity of speech, imagery of language.

The method of instruction - has an informative local character, close to the order of the algorithmic type. It is used in laboratory, practical classes, as well as in preparation for independent work. According to the content, there are introductory, current and final briefings. During the introductory briefing, students are acquainted with the content of future work and the means of its implementation, explain the rules and sequence of work in general and its individual parts, methods of work, indicate possible errors; get acquainted with the rules of safety, workplace organization. Current instruction is carried out mainly individually in the process of students' work.

Monological form of teaching - a story. It is used if necessary to present the training material systematically, consistently. The elements of the story are an accurate description, narrative, rationale for the facts. Stories are divided into artistic, popular science, descriptive. Each type of story should provide an educational focus of learning, be based on reliable scientific facts, focus on the main idea, be accessible and emotional, contain conclusions and comments.

The method of teaching, according to which the teacher with the help of questions encourages students to reproduce the acquired knowledge, the formation of independent conclusions and generalizations based on the acquired material - conversation. According to the purpose in the educational process there are: introductory conversation (conducted in preparation for a seminar, excursion, study of new material); conversation-message (based mainly on observations organized by the teacher in the classroom with the help of visual aids, as well as on the materials of texts of literary works, documents); conversation-repetition (used to consolidate educational material); control conversation (resort to it when checking the acquired knowledge). According to the nature of students' activity, reproductive conversation is distinguished (aimed at reproducing the mastered material); heuristic, or Socratic (the teacher directs students to the formation of new concepts, conclusions, rules, using the acquired knowledge, observations); catechetical (aimed at reproducing statements that require literal 
memorization). The effectiveness of any type of conversation depends on the skillful formulation of questions, as well as on the quality of answers, their completeness, clarity, argumentation.

Educational discussion - is a public discussion of an important issue and involves the exchange of views between students or teachers and students. It develops independent thinking, the ability to defend their own views, analyze and argue statements, critically evaluate other people's own judgments. During the educational discussion, scientific conclusions are discussed, data that need to be prepared according to sources that contain broader information than the textbook. The discussion is aimed not only at mastering new knowledge, but also at creating an emotionally rich atmosphere that would contribute to a deep penetration into the truth.

Visual teaching methods include: illustration, demonstration, independent observation [2]. Their essence is to use images of objects and phenomena.

The first method is to demonstrate illustrated manuals, posters, geographical and historical maps, diagrams, drawings on the board, paintings, photographs, models. Plants, animals, minerals, and machinery are often illustrated directly in the educational process. Illustrations facilitate the perception of educational material, contribute to the formation of specific ideas, precise concepts.

The second method involves the display of materials in the dynamics (the use of instruments, experiments, equipment). It is effective when all students have the opportunity to perceive a subject or process. The teacher focuses on the main thing, helps to highlight the essential aspects of the subject, the phenomenon, accompanying the show with an explanation, a story. Demonstrating models, production processes at the enterprise, it is necessary to take care of observance of safety rules.

Independent observation is a direct independent perception of the phenomena of reality in the process of learning. The method of organizing any observation involves several stages: instruction on the purpose, objectives and methods of observation; fixation, selection, analysis and generalization of its results. The work done must be evaluated.

Methods of practical training include various activities of students and teachers, as well as the independence of students in learning. These include exercises, laboratory and practical work.

In essence, the exercises are repeated repetition of certain actions or activities in order to master them, which is based on understanding and is accompanied by conscious control and adjustment. The following types of exercises are used: preparatory, introductory, trial, training, creative, control. The number of exercises depends on the individual characteristics of students and should be sufficient for the formation of skills. Exercises should be based on a system, a clearly planned sequence of actions, a gradual complication. It is desirable not to interrupt the use of exercises for a long time. The effectiveness of the exercise depends on the analysis of its results.

The value of laboratory work as a method is that they contribute to the connection of theory with practice, equip students with research methods in nature, develop skills in using devices, teach to process measurement results and draw correct scientific conclusions.

Being a method of teaching - practical work is aimed at developing skills and abilities necessary for life and self-education. Execution of such works helps to concretize knowledge, develops the ability to observe and explain the essence of phenomena.

The most common among the methods of logical thinking, the principle of separation and unification are induction and deduction (methods of analysis, synthesis, comparison, generalization, specification, selection of the main).

Induction is usually resorted to at the empirical level of knowledge, when the material is factual or related to the formation of concepts, as well as during the study of technical mechanisms, practical tasks, solving mathematical or physical problems.

The transition from general to specific in the process of learning involves deduction. The teacher first communicates the general provisions, formula, law, which lead to the gradual solution of specific problems. Both methods are implemented through the use of verbal, visual, practical, as well as problem-based and partial-search methods.

The application of teaching methods in higher education depends not on the methods themselves, but on the pedagogical qualifications and skills of the teacher, but mainly on the model of teaching and the level of students' knowledge of the subject at each psychological and pedagogical stage.

There are several models of teaching methods: passive, active and interactive teaching methods. Passive teaching methods - a method of interaction between teacher and student, in which the teacher is the main actor and leader of the lesson, and students act as passive students who follow the instructions of the teacher. 
Active teaching methods - a method of interaction between student and teacher, in which they interact with each other during the lesson and students are active participants, teacher and student are equal.

Interactive teaching methods - a method of teaching in the cooperation of teacher and student, in which the participants interact with each other, exchange ideas, solve problems together, model situations.

Interactive teaching methods perform the function of problem-based learning, which helps to develop students' clinical thinking, forms independence. Interactive learning is based on the interaction of all students, including the teacher. The teacher often acts only as an organizer of the learning process, group leader, facilitator, creates conditions for initiative and activity of students.

The interactive teaching method used in higher medical education is a small group method and is the main one. Teaching students in small groups allows them to acquire skills of cooperation, communication, interpersonal skills, participate in discussions, debates, forms decision-making skills, leadership skills and abilities. When organizing studies, it is better to unite students in small groups (3-4 people), because such a number of students in a group is more effective because they are faster to organize, work better and give each student more opportunities in the learning process.

In groups of two people there is a high level of information exchange and less differences, but higher and the likelihood of greater tension, emotionality and, very often, a potential impasse. In case of disagreement, neither participant has an ally.

Groups of three students are the most stable group structures with periodically emerging displaced coalitions. In this case, it is easier to settle differences.

The size of the group of five is the most satisfactory for training. Distribution of opinions in a ratio of 2: 3 provides support for the minority. Such a group is large enough to simulate situations and small enough to engage all participants in work and personal encouragement.

The purpose of the "brainstorming" is to receive from the group in a short time a large number of answer options. He can demonstrate what students know; in the course of this method ideas can be offered that can solve the problem, a structure of exchange of views on general experience and wishes of students are created. Brainstorming is a tool for forming such abilities of students as: the ability to express their opinions, the ability to communicate, the ability to make decisions, the ability to work in a group, to be creative. The essence of the process is that the group is given a topic, question or unfinished proposal. For a few minutes, the group members discuss the topic, everything that comes to mind, and all this is recorded. Everything is recorded, no matter how vague or controversial it may be. So far, everyone is just speaking and there is no discussion yet, as the goal is to get a lot of different proposals. The first sentences are followed by other ideas, as the imagination works smoothly. At this time there are no prohibitions and no assessments are given; participants have the opportunity to later analyze the proposals, disagree and discuss all the proposed ideas. If the activity is weak, the teacher-facilitator may offer to write down some of his ideas. But before doing so, he must pause [3].

Another method of interactive learning is discussion. It is used to discuss the results of tasks in practical and laboratory classes, when students need to speak. In the lecture, the discussion in the full sense, can not be held, but the discussion question, which is given several different answers from the audience, without choosing the final, most correct of them, creates an atmosphere of collective reflection and willingness to listen to the teacher responsible for this discussion. question.

In a practical (seminar) lesson, the discussion requires thoughtfulness and thorough preliminary training of students. Not only sound education but his alertness and dedication too are most required. Educational discussions enrich students' ideas on the topic of the lesson, organize and consolidate their knowledge.

Discussion is one of the types of interpersonal communication, and this activity is leading in the modern educational process. One of the main values of the discussion is not so much a comprehensive and deep solution to the problem, as the motivation of participants to think about it, as well as to review their beliefs and ideas, clarify and define their position, learn to argue their own point of view, and at the same time the right of others to have their own view on the issue under discussion, to be an individual.

Methods of research and organizational organization of students involve the creation of problem situations with the teacher together with students, encourages them to independent practical work on collecting and systematizing facts (students select actual material from books or experiments), search activities (analysis of facts, problem statement and solution), organizes creative, independent work, gives problem tasks with the indication of the purpose of work (problem situations arise during performance of the educational 
tasks having not only theoretical, but also practical value). This creates a high (research-heuristic) level of problem, inherent in the activity in a new situation, the algorithm of which is unknown (the activity is dominated by heuristic procedures related to hypotheses, search and use of analogy in reasoning).

The project method involves achieving the goal through a detailed solution of the problem, which must result in a practical result. Search and research projects require a well-thought-out structure, a defined goal, the relevance of the subject of research for all participants of social significance, thoughtful methods. They are completely subordinated to the logic of research and have an appropriate structure: defining the research topic, arguing its relevance, defining the subject and object, tasks and methods, defining research methodology, hypotheses and solving ways to solve it.

The method of scientific research provides the formation of skills:

- fundamental, with the highest degree of uncertainty, the result of which is the discovery of new phenomena and laws of science, the expansion of scientific knowledge of medicine and their application in the practice of medicine;

- applied, involving the search for new or improvement of already known phenomena and laws of science, the purpose of which is to use the obtained results in the practice of the doctor.

Individual educational and research tasks are a type of extracurricular individual work of a student of educational, research or project type, which is performed in the process of studying the program material of the training course and ends with a final exam or test. Among the individual educational and research tasks the most common are: a synopsis of the topic (module) according to a given plan or a plan that the student has developed independently; abstract on the topic (module) or narrow issues; solving and compiling practical problems of different levels on the topic (module) or course; development of theoretical or applied (current) functional models of phenomena, processes, structures; comprehensive description of the structure, properties, functions, phenomena, objects, structures; annotation of the read additional literature from the course, bibliographic description.

The problem of practical health care is not that doctors do not recognize and do not know how to treat the rarest diseases, but that they often do not diagnose and do not always effectively treat the most common, important diseases that make up the bulk of morbidity and mortality of people. Therefore, the meaning of educational modeling with the help of diagnostic and therapeutic tasks, problem situations and especially business games - to provide high professional training, at this level, vital for every doctor - to work flawlessly in a very typical environment.

The form of business game in medicine is - reproduction of subject and social maintenance of professional activity of the doctor, modeling of systems of relations "doctor-patient", "doctor-doctor", "doctorrelatives of the patient”, "doctor-other expert”. Application of business games in medicine: 1) immersion in the atmosphere of imitation of professional activity, extremely close to professional, practical work of the doctor in recognition of diseases and treatment of patients; 2) creating a dynamic change in the picture of the disease depending on the right and wrong actions and decisions; 3) carrying out differential diagnosis by the shortest way, the minimum time and appointment of optimum tactics of treatment by the simplest and accessible methods of treatment.

Researchers of the problem of game simulation believe that the situations that underlie each game should be relevant, real, typical, complete, capable of growth and development of situations. But in medicine it is necessary to take into account the problem of rare patients. Clinicians of all profiles know that many of the diseases covered by the curriculum are rare and it is often not possible to show students real patients. And here the educational game on this topic compensates for the absence of the patient.

In business games in medicine it is necessary to provide completeness of situations. When developing such a game, one should strive to ensure that in addition to the information necessary and sufficient for diagnosis, "information noise» must be included - excessive information, which, however, is always used by most doctors. These are complex laboratory tests, numerous instrumental studies.

Business games in medicine are research, production and training. The main purpose and meaning of the latter is the training of specialists, their training and the development of professional skills to the level of high qualification. Different forms of games have different purposes. The purpose of research games is to test hypotheses, accumulate statistical data, search for new forms of organizations. Production games are used to improve, practice and adjust organizational, managerial, technological and other techniques and processes. Educational games are used for preparation and training, formation of narrow knowledge and development of abilities and skills. 
One of the effective teaching methods aimed at forming clinical thinking is the method of debriefing. Debriefing (in this case, knowledge from the participants of the game interaction) is a process of reviewing the judgments or opinions of the participants of interactive learning, as well as discussing and comparing their solutions with possible alternatives [4].

Conclusions and Prospects for Research. Thus, the variety of teaching methods, the requirements

\section{List of literature}

1. Дичківська І. М. Інноваційні педагогічні технології : підручник / I. М. Дичківська. - 2-ге вид., доповн. - К. : Академвидав, 2012. - 218 с.

2. Максименко С. Д. Науково-дослідницька діяльність студентів : методичні рекомендації для слухачів ФПК / С. Д. Максименко, М. М. Філоненко. - К., 2013. - 64 с.

\section{References}

1. Dychkivska, I.M. (2012). Innovatsiyni pedahohichni tehnolohii [Innovative pedagogical technologies]. (2nd ed.). Kyiv: Akademvydav [in Ukrainian].

2. Maksymenko, S.D., \& Filonenko, M.M. (2013). Naukovo-doslidnytska diialnist studentiv [Research activity of students]. Kyiv [in Ukrainian].

3. Ovcharuk, O.V. (2004). Rozvytok kompetentnisnoho pidhodu: stratehichni oriyentyry mizhnarodnoii spilnoty. for their choice force the teacher to optimally select teaching methods for each topic, to create their own methods of teaching subjects. Therefore, the method of teaching should be understood as a set of methods, techniques, teaching aids, which together contribute to the solution of didactic tasks. Pedagogical theory and practice of higher medical education show that there are no "pure" methods in teaching. All methods are closely interrelated.

3. Овчарук О. В. Розвиток компетентнісного підходу: стратегічні орієнтири міжнародної спільноти / О. В. Овчарук. - K. : K.I.C., 2004. - 112 с.

4. Fanning R. The role of debriefing in simulationbased learning. Simulation in Health care [Electronic resource] / R. Fanning, D. Gaba. - Access mode: https://www. metscenter.nl/wp-content/uploads/2016/12/Nice-The-Roleof-Debriefing-in-Simulation-Based-Learning.

[Development of competence approach: strategic guidelines of the international community]. Kyiv [in Ukrainian].

4. Fanning, R., \& Gaba, D. The role of debriefing in simulation-based learning. Simulation in Health care. Retrieved from: https://www.metscenter.nl/wpcontent/uploads/2016/12/Nice-The-Role-of-Debriefing-inSimulation-Based-Learning. 